Editors' Note: Lekhra gives 2 possible explanations for the wrong side dilated pupil in Wijdicks' case. Commenting on the clinical reasoning case regarding the unusual cause of transverse myelitis, Ghuman and Kaur discuss why the diagnosis of paraneoplastic myelopathy should have been in the differential. Bhargava and Elble explain why they disagree. -Chafic Karam, MD, and Robert C. Griggs, MD

\section{WRONG SIDE DILATED PUPIL}

Om Prakash Lekhra, Indore, India: I read the NeuroImage by Drs. Wijdicks and Giannini ${ }^{1}$ with interest. There are 2 possible explanations for the wrong side dilated pupil. The first possibility is that raised intracranial pressure caused kinking of the oculomotor nerve over the clivus, just posterior to the clinoid. Another alternative is that supratentorial pressure exerted dynamic axial brainstem distortion leading to contralateral dilated pupil. ${ }^{2}$

\section{Author Response: Eelco F. Wijdicks, Rochester,} MN: We appreciate these additional comments from Dr. Lekhra. In general, the third nerve can be compressed against the clivus, but it is difficult to unmistakably establish that with a routine autopsy procedure. Moreover, a relationship with a wrong side fixed pupil has not been shown.

C 2014 American Academy of Neurology

1. Wijdicks EFM, Giannini C. Wrong side dilated pupil. Neurology 2014;82:187.

2. Larner AJ. False localisings. J Neurol Neurosurg Psychiatry 2003;74:415-418.

\section{CLINICAL REASONING: AN UNUSUAL CAUSE OF} TRANSVERSE MYELITIS?

Mandeep S. Ghuman, Chandigarh; Shabdeep Kaur, Shimla, India: Bhargava and Elble ${ }^{1}$ excluded the common differentials of longitudinal transverse myelitis but overlooked paraneoplastic myelopathy (PNM). Cord lesions can still have an etiology despite biopsy-proven metastases in the brain. Having made the final diagnosis of small-cell lung carcinoma, the authors should have considered PNM.

Brain metastases are common in lung carcinomas, whereas intramedullary spinal cord metastases (ISCM) are very rare. PNM may be as rare as ISCM but, when present, PNM is often the presenting manifestation. CSF examination was equivocal. Paraneoplastic antibody workup has its limitations as only 60\%-70\% will have detectable antibodies. ${ }^{2}$ Regarding immunotherapy, there are no evidence-based recommendations and paraneoplastic syndromes mediated by antibodies are potentially reversible vs those with intracellular target antigens. ${ }^{2}$

Typical neuroimaging findings in PNM are symmetric, longitudinally extensive tract, or gray matter-specific changes, ${ }^{3}$ whereas ISCM lesions are usually solitary, in the thoracic spinal cord, located eccentrically within the cord and expanding the cord. ${ }^{4}$ Overall imaging features would favor PNM over ISCM. PET can differentiate between the 2 by demonstrating hypermetabolic foci in ISCM, and can play a pivotal role in certain clinical scenarios: when MRI is contraindicated and when there is suspicion of ISCM with equivocal spinal cord magnetic resonance findings in those who cannot receive IV gadolinium. ${ }^{5}$

Author Response: Pavan Bhargava, Baltimore; Rodger J. Elble, Springfield, IL: The authors thank Drs. Ghuman and Kaur for their comments. In this case, we agree that it was not possible to definitively rule out PNM. However, there are several factors that make this diagnosis unlikely. PNM is commonly associated with moderate CSF lymphocytic pleocytosis, elevated protein, and sometimes oligoclonal bands in the CSF. ${ }^{6}$ Multiple CSF analyses in our patient were normal. The incidence of PNM is far lower than that of spinal cord metastases (SCM), which can occur in $0.1 \%-0.4 \%$ of all cancer patients. ${ }^{7}$ Invoking Occam razor, the simplest explanation for the spinal cord findings would be a SCM. In addition, the MRI spine is consistent with $\mathrm{SCM}^{8}$ especially noting that the cord appears to be swollen at T8 with maximal abnormality in that area. ${ }^{1}$ Whereas a PET scan may have helped, studies have shown that PET imaging can miss up to $30 \%$ of SCM, so it would not have been definitive. ${ }^{9}$ The lack of response to immunotherapy, presence of multiple brain metastases, and an advanced stage lung cancer make the diagnosis of SCM far more likely than PNM.

\section{2014 American Academy of Neurology}

1. Bhargava P, Elble RJ. Clinical Reasoning: An unusual cause of transverse myelitis? Neurology 2014;82:46-50. 
2. Kannoth S. Paraneoplastic neurologic syndrome: a practical approach. Ann Indian Acad Neurol 2012;15:6-12.

3. Flanagan EP, McKeon A, Lennon VA, et al. Paraneoplastic isolated myelopathy: clinical course and neuroimaging clues. Neurology 2011;76:2089-2095.

4. Rykken JB, Diehn FE, Hunt $\mathrm{CH}$, et al. Intramedullary spinal cord metastases: MRI and relevant clinical features from a 13-year institutional case series. AJNR Am J Neuroradiol 2013;34:2043-2049.

5. Mostardi PM, Diehn FE, Rykken JB, et al. Intramedullary spinal cord metastases: visibility on PET and correlation with MRI features. AJNR Am J Neuroradiol 2014;35: 196-201.
6. Flanagan EP, Keegan BM. Paraneoplastic myelopathy. Neurol Clin 2013;31:307-318.

7. Belaid I, Jlassi H, Debbiche G, Rais H, Ben Ayed F. Lung adenocarcinoma with intramedullary spinal cord metastasis: a case report and review of the literature [French]. Rev Pneumol Clin 2013;69:149-151.

8. Nishioka K, Tanaka R, Tsutsumi S, et al. Longitudinally extensive transverse myelitis with intramedullary metastasis of small-cell lung carcinoma: an autopsy case report. Case Rep Neurol Med 2013;2013:305670.

9. Mostardi PM, Diehn FE, Rykken JB, et al. Intramedullary spinal cord metastases: visibility on PET and correlation with MRI features. AJNR Am J Neuroradiol 2014;35:196-201.

\section{WriteClick: Rapid Online Correspondence}

The editors encourage comments about recent articles through WriteClick:

Go to www.neurology.org and click on the "WriteClick" tab at the top of the page. Responses will be posted within 72 hours of submission.

Before using WriteClick, remember the following:

- WriteClick is restricted to comments about studies published in Neurology within the last eight weeks

- Read previously posted comments; redundant comments will not be posted

- Your submission must be 200 words or less and have a maximum of five references; reference one must be the article on which you are commenting

- You can include a maximum of five authors (including yourself)

\section{Guide the Future of Neurology—Become a Mentor!}

The Academy's Neurology Career Center is working to bring experienced members together with members who seek guidance on their career path. AAN Mentor Connect needs volunteer Mentors who are willing to share their expertise, insights, and experiences with Mentees.

This flexible program, available only to AAN members, matches prospective Mentors and Mentees, and enables you to develop a plan with the Mentee that has a mutually agreeable schedule and expectations.

Enjoy the personal satisfaction of making a valued contribution to the career of a fellow AAN member. Visit www.ann.com/view/Mentor to learn more and register to be a Mentor today. 


\section{Neurology}

\section{Clinical Reasoning: An unusual cause of transverse myelitis? \\ Mandeep S. Ghuman, Pavan Bhargava, Shabdeep Kaur, et al. Neurology 2014;83;666-667 \\ DOI 10.1212/01.wnl.0000453452.93496.2c}

\section{This information is current as of August 11, 2014}

\section{Updated Information \&} Services

References

Permissions \& Licensing

Reprints including high resolution figures, can be found at: http://n.neurology.org/content/83/7/666.2.full

This article cites 9 articles, 4 of which you can access for free at: http://n.neurology.org/content/83/7/666.2.full\#ref-list-1

Information about reproducing this article in parts (figures,tables) or in its entirety can be found online at:

http://www.neurology.org/about/about_the_journal\#permissions

Information about ordering reprints can be found online: http://n.neurology.org/subscribers/advertise

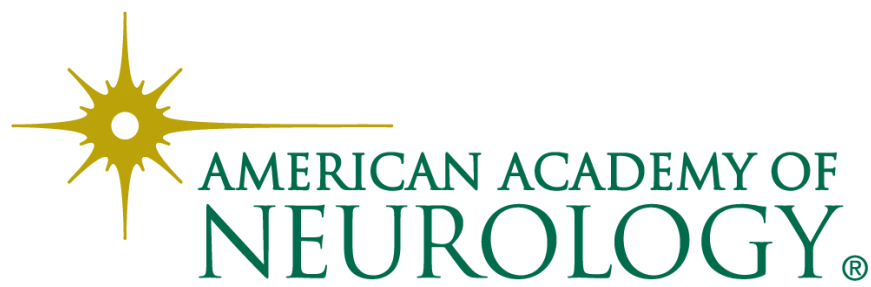

